\title{
OVARIAN ESTROGEN SECRETION DURING THE ESTROUS CYCLE AND UNDER THE INFLUENCE OF EXOGENOUS GONADOTROPINS IN RATS
}

\author{
TAKashi HORI, Makoto IDE and Tamotsu MIYAKE \\ Shionogi Research Laboratory, Shionogi and Co., Ltd., Osaka
}

\begin{abstract}
SYNOPSIS
The concentration of free estrogen in $1 \mathrm{ml}$ of fractionated plasma obtained from the ovarian venous blood of rats showing a regular 4-day cycle was determined by a bioassay method based on 2,3,5-triphenyltetrazolium chloride reduction in the mouse vagina. A significant amount of estrogen, $0.2 \mathrm{ng} / \mathrm{ml}$ plasma of estradiol equivalent, was detected in the ovarian venous blood plasma during diestrus Day 1 and on the morning of diestrus Day 2. The estrogen level markedly elevated in the afternoon of diestrus Day 2 and continued to rise up to a peak $(4.5 \mathrm{ng} / \mathrm{ml})$ before noon of proestrus. The highly elevated estrogen level sharply declined about $10 \mathrm{hrs}$. prior to ovulation when LH was supposedly released from the pituitary. No significant increase of estrogen level was seen thereafter until diestrus Day 2 of the next cycle. A sharp decline of ovarian venous blood estrogen to the level of diestrus was induced within $3 \mathrm{hrs}$. after removal of the pituitary in the afternoon of proestrus when estrogen secretion was highly stimulated. Intravenous injection of gonadotropin, $250 \mu \mathrm{g}$ of NIH-FSH-S or NIH-LH-S $_{3}$, caused a significant stimulation of the ovarian estrogen secretion in the rat hypophysectomized at proestrus. The mechanisms controlling the ovarian estrogen secretion in the rat were discussed.
\end{abstract}

In spite of recent technical advances in the measurement of estrogen (Ittrich, 1958; Svendsen, 1960; Wotiz et al., 1967), the detection of the in vivo secretion of ovarian estrogen in the rat has been unsuccessful. A great number of previous investigations on pituitary-ovarian physiology have been based on biological phenomena which are sensitive to estrogen and may reflect the endogenous estrogen level. However, the direct measurement of estrogen secretion from the ovary would be essential to clarify more definitely the pituitary-ovarian relationship during the process of the reproductive cycle and to elucidate the mechanism regulating in vivo ovarian steroidogenesis.

A sensitive and specific estrogen bioassay

Received for publication December 4, 1967. based on the vaginal tetrazolium reduction in spayed mice (Martin, 1960; Hori, 1964a and b; Hori and Miyake, 1964, 1965, 1966) made it possible to determine an extremely low level of estrogen in the blood. In this study, an attempt was made to determine the estrogen level in the ovarian venous blood plasma of individual rats during the estrous cycle.

\section{MATERIALS AND METHODS}

\section{Blood collection}

Female rats of the Wistar strain, weighing 150 to $250 \mathrm{~g}$, were used. The animals were maintained at $25^{\circ} \mathrm{C}$ with $12 \mathrm{hrs}$. of automatic lighting from 8 A.M. to 8 P.M. The stage of the estrous cycles was determined by checking vaginal smears every morning from 9 to 10 A.M. The rats exhibiting regular 4 day estrous cycles were used 
after confirming at least 2 normal cycles. Blood samples, a few $\mathrm{ml}$ of each, were collected at specified times of early diestrus (diestrus I), late diestrus (diestrus II), proestrus and estrus.

In the study on the relation between estrogen secretion and pituitary factors, the rats were hypophysectomized on 2 P.M. of proestrus by the intra-aural method (Tanaka, 1955) under methylhexabital sodium anesthesia. Two hrs. after surgery, NIH-FSH-S 1 or NIH-LH-S ${ }_{3}$ was injected into the tail vein at a volume of $0.5 \mathrm{ml}$ saline per injection.

Under pentobarbital sodium anesthesia, the rats were injected into the femoral vein with a heparin solution (200 unit/0.2 ml/rat). After laparotomy, an injection-needle (24 gauge, i.v. purpose, without joint) connected with silicon tubing (Fuji Polymer Industries, inside diameter $0.5 \mathrm{~mm}$, outside diameter $1.0 \mathrm{~mm}$ ) was inserted into a unilateral ovarian vein. The blood dripping through the tubing was collected into a centrifuge tube for 30 mins. and the volume was recorded. The blood sample was then centrifuged and the plasma was kept frozen until extraction.

\section{Fractionation of plasma}

One $\mathrm{ml}$ plasma was diluted with distilled water and the volume was adjusted to $20 \mathrm{ml}$. The diluent was extracted 4 times with 20, 10, 10 and $10 \mathrm{ml}$, respectively, of ether by mild stirring in a mechanical shaker. The ether fraction was washed with $10 \mathrm{ml}$ of concentrated carbonate buffer ( $\mathrm{pH} 10.5$ ), sodium bicarbonate $(1 \mathrm{M})$ and a small amount of water (Brown, 1955). Then the solvent was evaporated. The residue was dissolved in $3 \mathrm{ml}$ of $50 \%$ methanol and partitioned 3 times against $n$-hexane using $2 \mathrm{ml}$ each time. The methanol layer was evaporated in vacuo and the residue was transferred into a small test tube using a small amount of ether. This was dried again under a nitrogen stream. Immediately before bioassay, $100 \mu$ of water was added into the tube and the residue was then suspended by vigorous shaking with a Thermomixer for a few mins.

\section{Bioassay}

Estrogenic activity of the plasma extract was measured by the mouse tetrazolium assay, essentially the same as described by Martin (1960). Female albino mice of our DS strain were ovariectomized at 30 to 32 days of age. Ten days after castration, a group of 8 mice received a single intravaginal injection of $1 / 10$ of the plasma extract suspension, that is, $10 \mu \mathrm{l}$ per vagina. Twenty-seven hrs. later, animals received an intravaginal injection of $1 \mathrm{mg}$ of 2, 3, 5-triphenyltetrazolium chloride (TTC) dissolved in $20 \mu \mathrm{l}$ of water .Thirty mins. later, the animals were autopsied and the vaginae were isolated. The amount of formazan formed in the vagina during 30 mins. was extracted with $1.5 \mathrm{ml}$ of $3: 1$ ethanol-tetrachloroethylene and read at $490 \mathrm{~m} \mu$ with a Coleman spectrophotometer Junior 6C. The potency of the plasma in terms of estradiol equivalent was usually calculated from a 2-point assay (Burn et al., 1950), using $100 \mathrm{pg}$ of estradiol as standard on the basis of the combined slope obtained from a preliminary experiment described in the next section.

\section{RESULTS}

\section{Preliminary experiments on the determination} of estrogenic activity of the plasma

Although the tetrazolium test has made it possible to detect an estrogenic activity which is produced by even less than $50 \mathrm{pg}$ of estradiol (Martin, 1960; Hori, 1964a), a purification of ether extracts of plasma is necessary for the bioassay of blood estrogen, because it was shown that the crude extracts involving a considerable amount of plasma lipids caused a serious inhibition of the vaginal response to estrogen. All the several different systems of chromatography tried for purification yielded a low recovery and a poor reproducibility. It was finally proven that a simple purification procedure, fractionation of plasma, described in the previous section was enough to eliminate the substance interfering with the estrogen bioassay of plasma extract. The recovery of estrogen was determined by adding 900 pg of tritiated estradiol$17 \beta(0.01 \mu \mathrm{Ci})$ into $1 \mathrm{ml}$ of plasma obtained from a castrated male rat. The recovery of 
added radioactivity in the final methanol solution was equal to $91 \pm 3.3 \%$ (S.E.) in an average of 4 experiments, indicating no significant loss of estradiol during the purification procedures.

Table 1 represents the results of preliminary experiments for the determination of estrogenic activity involved in plasma. No estrogenic activity is detected in the plasma samples of 3 or $1 \mathrm{ml}$ each obtained from castrated males and castrated females. It is clear that the plasma extracts do not affect the vainal response to $1 \mathrm{ng}$ of estradiol, indicating a good separation of interfering materials from the extract. The linearity of the doseresponse line of the standard estradiol by the tetrazolium assay has previously been obtained in the range of $5 \mathrm{pg}$ to $100 \mathrm{pg}$ per animal and it may be extended above the upper limit (Hori, 1964a). Subsequently, a series of 10 repeated assays on estradiol were run at the same two dosages. The results are presented in Figure 1, indicating a good reproducibility of the slopes for dose-response relations of estradiol. The 5 samples of plasma extracts obtained from ovarian venous blood of the proestrus rats were also assayed for their estrogenic activity. Almost the same slope was obtained for each of the doseresponse regressions which are parallel with those of estradiol (Fig. 1). Therefore, a 2-

Table 1. Preliminary experiments to determine estrogenic activity in plasma

\begin{tabular}{|c|c|c|}
\hline $\begin{array}{c}\text { Designation } \\
\text { of } \\
\text { samples }\end{array}$ & $\begin{array}{l}\text { No. of } \\
\text { determination }\end{array}$ & $\begin{array}{c}\text { Formazan } \\
\text { production } \\
(1,000 \times \text { O.D. })\end{array}$ \\
\hline Blank & 9 & $48 \pm 5^{a}$ \\
\hline Estradiol $0.1 \mathrm{ng} /$ tube & 10 & $117 \pm 8$ \\
\hline Estradiol $1 \mathrm{ng} /$ tube & 10 & $326 \pm 13$ \\
\hline $\begin{array}{l}\text { Castrated male rat } \\
\text { plasma extract } 3 \mathrm{ml} \\
\text { e.q./tube }\end{array}$ & 7 & $51 \pm 6$ \\
\hline $\begin{array}{l}\text { Castrated female rat } \\
\text { plasma extract } 1 \mathrm{ml} \\
\text { e.q./tube }\end{array}$ & 2 & 63 \\
\hline $\begin{array}{l}\text { Castrated male rat } \\
\text { plasma extract } 3 \mathrm{ml} \\
\text { e.q. + estradiol } \\
1 \mathrm{ng} \text { tube }\end{array}$ & 5 & $330 \pm 26$ \\
\hline \multicolumn{3}{|c|}{$\begin{array}{l}\text { One determination consists of } 7 \text { to } 8 \text { mice. } \\
\text { One-tenth of the standard estrogen and/or plasma } \\
\text { extracts were injected intravaginally. } \\
\text { a) Mean } \pm \text { S.E. } \\
\text { b) Estradiol was added into the plasma extracts } \\
\text { before bioassay. }\end{array}$} \\
\hline
\end{tabular}

Table 2. Change in ovarian venous blood free estrogen level during the estrous cycle in rats

\begin{tabular}{|c|c|c|c|c|}
\hline $\begin{array}{c}\text { Stage of } \\
\text { estrous cycle }\end{array}$ & $\begin{array}{l}\text { No. of } \\
\text { rats }\end{array}$ & $\begin{array}{l}\text { Average } \\
\text { body } \\
\text { weight }(\mathrm{g})\end{array}$ & $\begin{array}{l}\text { Uterine weight } \\
\left(\begin{array}{c}\mathrm{mg} / 100 \mathrm{~g} \\
\text { body weight }\end{array}\right)\end{array}$ & $\begin{array}{c}\text { Estrogen } \\
\text { concentration } \\
\left.(\mathrm{ng} / \mathrm{ml} \text { plasma })^{\mathrm{a}}\right)\end{array}$ \\
\hline \multicolumn{5}{|l|}{ Diestrus I } \\
\hline $10 \mathrm{AM}$ & 15 & 215 & $143.2 \pm 4.2^{b)}$ & $\left.0.16 \pm 0.05^{b}\right)$ \\
\hline \multicolumn{5}{|l|}{ Diestrus II } \\
\hline $10 \mathrm{AM}$ & 6 & 190 & $143.8 \pm 13.3$ & $0.20 \pm 0.04$ \\
\hline 7 PM & 8 & 194 & $194.3 \pm 13.4$ & $1.38 \pm 0.49$ \\
\hline \multicolumn{5}{|l|}{ Proestrus } \\
\hline $9 \mathrm{AM}$ & 10 & 220 & $219.8 \pm 7.2$ & $2.32 \pm 0.70$ \\
\hline $11 \mathrm{AM}$ & 10 & 210 & $224.9 \pm 9.2$ & $4.51 \pm 0.92$ \\
\hline 2 PM & 10 & 194 & $254.5 \pm 12.1$ & $3.81 \pm 1.12$ \\
\hline $4 \mathrm{PM}$ & 10 & 200 & $244.8 \pm 12.9$ & $3.50 \pm 1.06$ \\
\hline $6 \mathrm{PM}$ & 10 & 207 & $243.4 \pm 16.8$ & $3.37 \pm 0.76$ \\
\hline $7 \mathrm{PM}$ & 13 & 202 & $239.0 \pm 10.1$ & $2.81 \pm 0.64$ \\
\hline 9 PM & 10 & 183 & $220.4 \pm 11.3$ & $0.66 \pm 0.22$ \\
\hline $11 \mathrm{PM}$ & 7 & 199 & $260.2 \pm 11.7$ & $0.09 \pm 0.05$ \\
\hline \multicolumn{5}{|l|}{ Estrus } \\
\hline $10 \mathrm{AM}$ & 15 & 214 & $195.1 \pm 5.4$ & $0.13 \pm 0.04$ \\
\hline
\end{tabular}

a) Estradiol equivalent b) Mean \pm S.E. 
point assay design (Burn et al., 1950) is available for the determination of blood estrogen by the aid of a combined slope for the standard. A set of 6 experiments according to the 2-point assay design were run on the plasma samples of castrated males and females to which 0.1 and $1 \mathrm{ng}$ of estradiol were added, respectively, and a mean recovery of $87 \pm 14 \%$ (S.E.) was achieved. It is sug- gested, therefore, that as little as $50 \mathrm{pg} / \mathrm{ml}$ plasma of estradiol can be practically measured by this method.

\section{Estrogen concentration in ovarian venous} blood plasma during the estrous cycle of rats

A few $\mathrm{ml}$ each of ovarian venous blood were collected from the rats at specified times in various stages of the estrous cycle and the

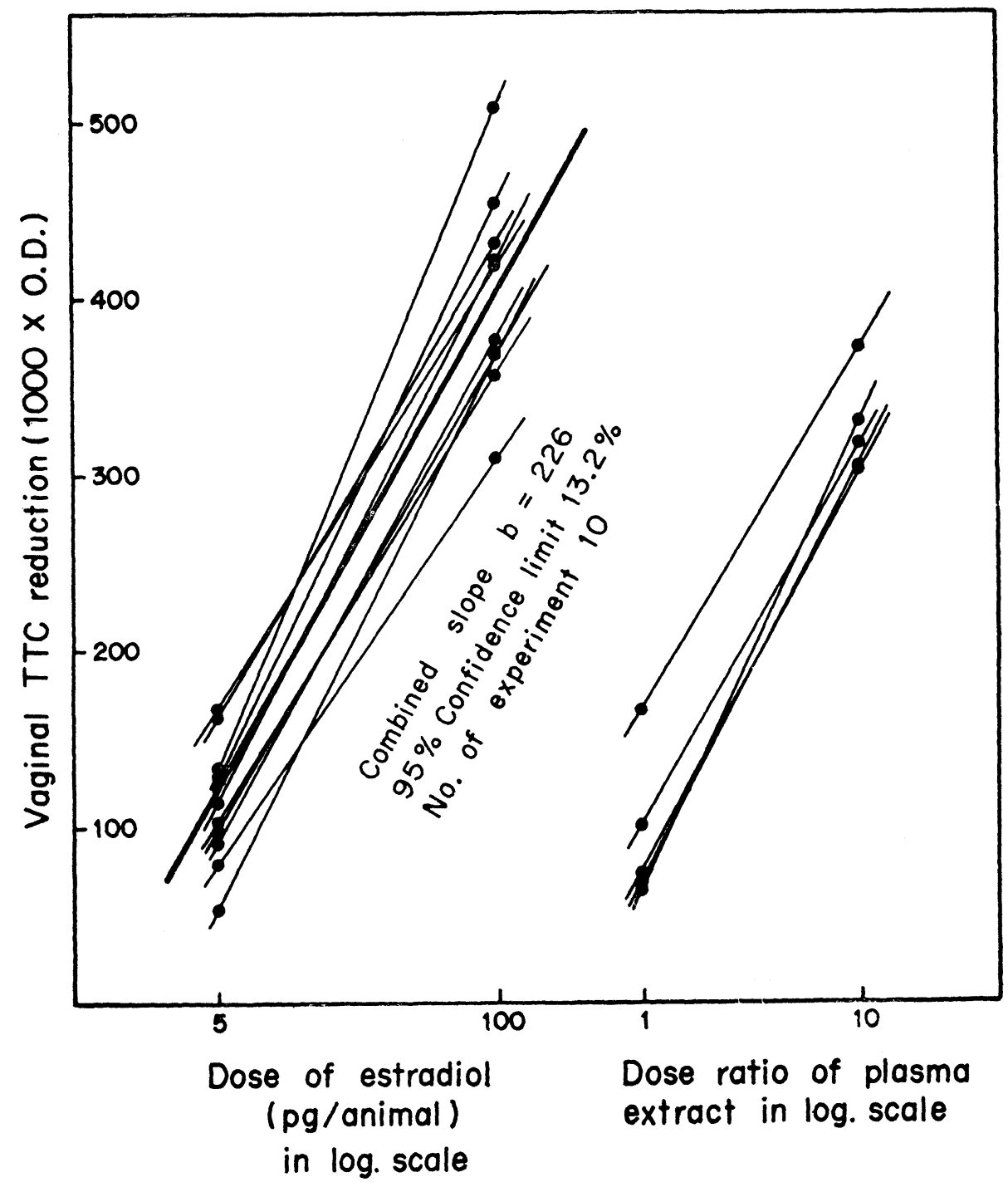

Fig. 1. The reproducibility of tetrazolium assay. Each plot represents the mean value of the group consisting 8 animals. Note that there is no significant difference in slope between estradiol and plasma extracts. 
estrogen concentration in the fractionated plasma was determined to elucidate the chronological pattern of estrogen secretion during the estrous cycle. The results are shown in Table 2 and Figure 2.

Only a slight but significant estrogenic activity, approximately $0.2 \mathrm{ng} / \mathrm{ml}$ plasma of estradiol equivalent, was detected in the ovarian venous blood plasma in the morning of either the first (diestrus I) or the second (diestrus II) day of diestrus. The estrogen concentration greatly increased in the afternoon of diestrus II, and it was further elevated in the following morning (proestrus) and reached a maximum before the noon of pro- estrus. The highly elevated estrogen secretion was maintained for several hours and then sharply declined after 7 P.M. of proestrus. At 11 P.M. of proestrus, the plasma estrogen concentration was as low as one-fiftieth of that found at 11 A.M. on the same day. No significant increase of the estrogen level occurred until diestrus II of the next cycle. As illustrated in Figure 2, the time-course of uterine weight closely paralleled that of the ovarian venous blood estrogen until the morning of proestrus, but a few hrs. of delay in the peak and a gentle descending slope, which was contrasted with a rapid and sharp decline of estrogen secretion, were noticed

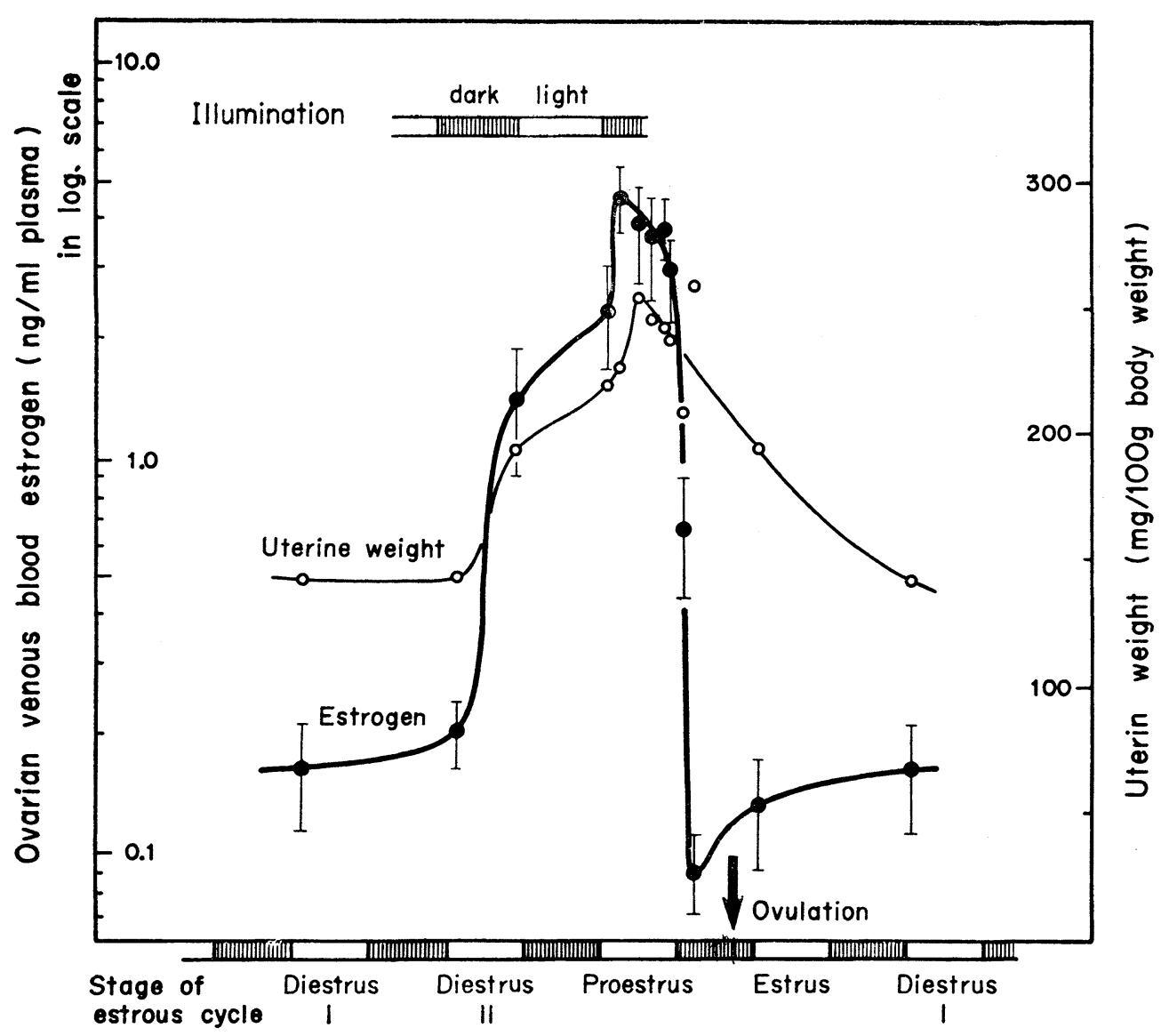

Fig. 2. Change in ovarian venous blood estrogen level during estrous cycle in rats. Vertical bars on the respective plots indicate the standard errors. 
Relation between pituitary factors and ovarian venous blood estrogen level

Table 3 presents evidence for the hypophyseal dependency of estrogen secretion from the rat ovary in proestrus. Animals were hypophysectomized at 2 P.M. in proestrus when the ovarian estrogen secretion was highly elevated. The estrogen concentration in ovarian venous blood drastically declined immediately after surgery and it fell to the level of diestrus within 180 mins., while the estrogen concentration in an anesthetized control showed only a tendency of slight decrease during the same period of time.
This indicates the necessity of some pituitary factor(s) for the secretion of estrogen from the ovary having well developed follicles.

The acute promoting effect of gonadotropins on the estrogen secretion in hypophysectomized rats is presented in Table 4. A certain dosage $(250 \mu \mathrm{g})$ of either gonadotropin, NIH-FSH or NIH-LH, caused a significant increase of estrogen secretion in the hypophysectomized rat. It should be noted that the estrogen level elevated by exogenous FSH is beyond the level of the intact rat at 11 A.M. in proestrus when the estrogen secretion is at a peak during the estrous cycle.

Table 3. Effect of hypophysectomy on the secretion of estrogen into the ovarian venous blood in the proestrus rat

\begin{tabular}{ccccc}
\hline \hline $\begin{array}{c}\text { Time after } \\
\text { surgery } \\
\text { (mins) }\end{array}$ & $\begin{array}{c}\text { No. of } \\
\text { rats }\end{array}$ & $\begin{array}{c}\text { Average } \\
\text { body } \\
\text { weight } \\
(\mathrm{g})\end{array}$ & $\begin{array}{c}\text { Uterine weight } \\
(\mathrm{mg} / 100 \mathrm{~g} \\
\text { body weight })\end{array}$ & $\begin{array}{c}\text { Estrogen } \\
\text { concentration } \\
(\mathrm{ng} / \mathrm{ml} \text { plasma) }\end{array}$ \\
\hline 0 & 10 & 194 & $\left.\left.254.5 \pm 12.1^{\mathrm{b}}\right)^{\mathrm{b}}\right)$ & $3.81 \pm 1.12^{\mathrm{b})}$ \\
45 & 5 & 176 & $225.2 \pm 18.7$ & $1.09 \pm 2.16$ \\
90 & 5 & 169 & $203.7 \pm 10.2$ & $0.59 \pm 0.08^{\dagger}$ \\
180 & 5 & 173 & $195.2 \pm 11.1$ & $0.29 \pm 0.06^{\dagger}$ \\
$\left.300^{\mathrm{c}}\right)$ & 8 & 194 & $224.0 \pm 10.8$ & $0.36 \pm 0.06^{\dagger}$ \\
Anesthetized control $_{180}$ & 5 & 209 & $241.4 \pm 2.1$ & $1.42 \pm 0.18$ \\
\hline
\end{tabular}

Rats were hypophysectomized at 2 PM in proestrus.

a) Estradiol equivalent, b) Mean \pm S.E. c) The data transfered from Table 4.

$\dagger$ Statistically significant against control group ( 0 mins.) at $\mathrm{p}<0.05$

Table 4. Effect of NIH-LH and NIH-FSH on the secretion of estrogen in ovarian venous blood of hypophysectomized rats in proestrus

\begin{tabular}{|c|c|c|c|c|c|}
\hline \multicolumn{2}{|c|}{ Treatment } & $\begin{array}{l}\text { No. of } \\
\text { rats }\end{array}$ & $\begin{array}{l}\text { Average } \\
\text { body } \\
\text { weight } \\
(\mathrm{g})\end{array}$ & $\begin{array}{l}\text { Uterine weight } \\
\left(\begin{array}{c}\text { mg } / 100 \mathrm{~g} \\
\text { body weight }\end{array}\right)\end{array}$ & $\begin{array}{c}\text { Estrogen } \\
\text { concentration } \\
\left.(\mathrm{ng} / \mathrm{ml} \text { plasma })^{\mathrm{a}}\right)\end{array}$ \\
\hline \multicolumn{2}{|c|}{$\begin{array}{l}\text { Intact control } \\
\text { (at } 7 \mathrm{PM} \text { in proestrus) }\end{array}$} & 13 & 202 & $239.0 \pm 10.1^{b)}$ & $2.81 \pm 0.64^{b}$ \\
\hline \multicolumn{2}{|c|}{$\begin{array}{l}\text { Hypophysectomized } \\
\text { control }\end{array}$} & 8 & 194 & $224.0 \pm 10.8$ & $0.36 \pm 0.06$ \\
\hline \multirow[t]{2}{*}{ NIH-LH-S ${ }_{3}$} & $25 \mu \mathrm{g}$ & 9 & 200 & $224.1 \pm 14.6$ & $1.52 \pm 0.31$ \\
\hline & $250 \mu \mathrm{g}$ & 8 & 194 & $273.0 \pm 17.6$ & $1.98 \pm 0.65^{\dagger}$ \\
\hline \multirow[t]{2}{*}{ NIH-FSH-S } & $25 \mu \mathrm{g}$ & 9 & 172 & $250.4 \pm 13.8$ & $0.76 \pm 0.13$ \\
\hline & $250 \mu \mathrm{g}$ & 8 & 189 & $283.0 \pm 17.8^{\dagger}$ & $5.78 \pm 1.59 \dagger \dagger$ \\
\hline
\end{tabular}

Rats were hypophysectomized at 2 PM in proestrus. Gonadotropins were injected intravenously

2 hrs. after surgery. Ovarian venous blood was collected $3 \mathrm{hrs}$. after gonadotropin injection.

a) Estradiol equivalent, b) Mean \pm S.E.

$\dagger$, $\dagger$ Statistically significant against hypophysectomized control at $\mathrm{p}<0.05$ and $\mathrm{p}<0.01$. 


\section{DISCUSSION}

The present experiments clearly demonstrate the cyclic fluctuation of the free estrogen level in the rat ovarian venous blood during the estrous cycle. A rapid increase of estrogen secretion occurs in the afternoon of diestrus II and it continues through the morning of proestrus until the estrogen level reaches a maximum around 11 A.M. The elevated estrogen level, which is approximately 15 to 20 times higher than the level at 10 A.M. of diestrus II, lasts more than 6 hrs., while in the next few hours it promptly decreases and at 11 P.M. it falls to a level below that of diestrus I. It is further demonstrated that the striking elevation of preovulatory estrogen secretion is under the control of the pituitary.

Kobayashi et al. (1968) in our laboratory made the simultaneous determination of pituitary $\mathrm{LH}$ and plasma $\mathrm{LH}$ concentrations during the estrous cycle of the rat in the same lighting schedule and determined the critical time of $\mathrm{LH}$ release for ovulation being from 5 to 7 P.M. of proestrus. This means that the ovulatory surge of $\mathrm{LH}$ occurs after the maximal elevation of estrogen secretion followed by an elevated secretion lasting about $6 \mathrm{hrs}$., and the drastic fall of estrogen secretion occurs during the LH release when the circulating amount of $\mathrm{LH}$ is abundant. It is considered, therefore, that the rapid elevation of estrogen secretion and its prolongation for several hours may cause the accumulation of LH in the pituitary (Kobayashi et al., 1968), and finally act as a trigger for the ovulatory release of $\mathrm{LH}$, but it is not likely that this LH surge elicits, in turn, the increased secretion of estrogen. These results support the stimulatory effect of estrogen on LH release but do not support the positive feedback relation between LH surge and estrogen secretion, which has been generally accepted in spite of deficient evidence. This also does not agree with the results of Ramirez and McCann (1964), who noticed the peak of plasma $\mathrm{LH}$ level coinciding with the increase of uterine weight in the rat and con- sidered that the ovulatory discharge of $\mathrm{LH}$ may stimulate estrogen secretion. The data obtained from our experiments indicate that the levels of uterine weight during proestrus are always high even after 7 P.M. when the estrogen secretion is remarkably reduced, indicating that the uterine weight change is not able to reflect the rapid change of estrogen secretion such as the prompt decrease which occurred after LH release.

Recently, a considerable amount of evidence has accumulated for the preovulatory secretion of progesterone in the rat (Eto et al., 1962; Telegdy and Endröczi, 1963; Lindner and Zmigrod, 1967). Uchida et al. (1968) in our laboratory also demonstrated that the tremendous increase of progesterone secretion occurred in the afternoon of proestrus at 7 P.M. to 11 P.M. in the same strain of rats under the same lighting schedule as we used. The chronological relation between the increase of estrogen secretion, LH release and preovulatory secretion of progesterone suggest that a quick shift from estrogen secretion to progesterone secretion occurs in the rat ovary approximately $10 \mathrm{hrs}$. before ovulation under the influence of $\mathrm{LH}$ release into the circulating blood. This does not agree with the hypothesis of Short (1964) who assumed from his experiments on mares that the cyclic changes of estrogen and progesterone secretions from the ovary merely resulted from indirect influences of pituitary gonadotropins which regulate the differentiation of follicles in the process of ovulation and luteinization.

As previously mentioned, a sharp decline of estrogen secretion immediately after hypophysectomy clearly indicates the pituitary dependency of estrogen secretion from the ovary having well developed follicles. The available evidence in relation to the acute promoting effect of gonadotropins on estrogen secretion are not sufficient as yet. It is noteworthy, however, that either LH or FSH administered intravenously is able to cause a prompt and remarkable increase of estrogen secretion in the rat hypophysectom- 
ized in the afternoon of proestrus.

Previous investigators (Fevold, 1941; Greep et al., 1942; Lostroh and Johnson, 1966) claimed that estrogen was produced only by the combined action of FSH with a small amount of LH in immature or hypophysectomized rats. These workers did not consider the difference between the dual effects of gonadotropins, an acute and delayed stimulatory effect on estrogen secretion, the latter of which is the result of proliferation and differentiation of ovarian cells. Recently, Short (1964) failed to demonstrate an acute influence of exogenous gonadotropin on the estrogen content of the ovarian venous blood of a mare in estrus. This paper may be the first case indicating such an acute promoting effect of gonadotropin on the in vivo estrogen secretion from the ovary. However, a problem remains to be solved as to whether a small amount of $\mathrm{LH}$ is essential for the acute stimulation of estrogen secretion by FSH. Further experiments involving the measurement of plasma FSH level during the estrous cycle are necessary to clarify the regulatory mechanism of estrogen secretion.

\section{ACKNOWLEDGEMENTS}

The authors gratefully acknowledge generous supplies of NIH-LH-S ${ }_{3}$ and NIH-FSH-S from the Endocrinology Study Section, National Institutes of Health, U.S.A. The technical assistance of Mr. Goro Kato through the completion of this work is also gratefully acknowledged.

\section{REFERENCES}

Brown, J. B. (1955). Biochem. J. 60, 185.

Burn, J. H. ,D. J. Finney and L. G. Goodwin. Biological Standardization 2nd ed. Oxford Univ. Press, London, p. 66 (1950).

Eto, I., H. Masuda, Y. Suzuki and T. Hosi (1962). Jap. J. Anim. Reprod. 8, 34.

Fevold, H. L. (1941). Endocrinology 28, 33.

Greep, R. O., H. B. Van Dyke and B. F. Chow (1942). Endocrinology 30, 635.

Hori, T. (1964a). Folia Endocrinol. Japon. 40, 1099. (In Japanese)

Hori, T. (1964b). Ibid. 40, 1106. (In Japanese)

Hori, T. and T. Miyake (1964). Endocrinol. Japon. 11, 159.

Hori, T. and T. Miyake (1965). Ibid. 12, 181. Hori, T. and T. Miyake (1966). Ibid. 13, 193. Ittrich, G. (1958). Z. physiol. Chem. 312, 1.

Kobayashi, F., K. Hara and T. Miyake (1968). Endocrinol. Japon. (in press).

Lindner, F. R. and A. Zmigrod (1967). Acta Endocrinol. 56, 16.

Lostroh, A. J. and R. E. Johnson (1966). Endocrinology 79, 991.

Martin, L. (1960). J. Endocrinol. 20, 187.

Ramirez, V. D. and S. M. McCann (1964). Endocrinology 74, 814.

Short, R. V. (1964). Recent Progr. in Hormone Research 20, 303.

Svendsen, R. (1960). Acta Endocrinol. 35, 161.

Tanaka, A. (1955). Annual Report of Shionogi Res. Lab. 5, 678.

Telegdy, G. and E. Endröczi (1963). Steroids 2, 119.

Uchida, K., M. Kadowaki and T. Miyake (1968). Folia Endocrinol. Japon. 44, 98.

$\checkmark$ Wotis, H. H., G. Charransol and I. N. Smith (1967). Steroids 10, 127. 